\title{
RANCANG BANGUN MESIN PEMOTONG KENTANG BERBENTUK STICK
}

\author{
Edi Irwan, Saparin, Eka Sari Wijianti, dan Yudi Setiawan \\ Jurusan Teknik Mesin Fakultas Teknik, Universitas Bangka Belitung \\ Desa Balunijuk, Kecamatan Merawang, Kabupaten Bangka \\ email : saparinpdca@gmail.com
}

\begin{abstract}
Abstrak
Penelitian ini merupakan rancang bangun mesin pemotong kentang. Tujuan akhir dari pembuatan mesin adalah produksi kentang berbentuk dadu. Dalam perencanaan mesin akan diproses untuk menghasilkan potongan kentang berbentuk stick. Desain mesin dibuat dengan dimensi $660 \mathrm{~mm}$ x $800 \mathrm{~mm}$ x $710 \mathrm{~mm}$ menggunakan motor listrik $1 / 2 \mathrm{Hp}$. Sistem penurunan putaran menggunakan pulley dan belt 1:2 dan diteruskan gearbox dengan rasio 1:40, cara kerja mesin adalah memutar poros engkol untuk menggerakan piston/penekan kentang dengan putaran 17,5 rpm. Penelitian dilakukan 3 kali dengan 1000 gram kentang dengan rata-rata hasil terpotong baik sebanyak 702 gram, tidak berhasil 27 gram, tertinggal 271 gram. Kapasitas produksi mesin pemotong kentang berbentuk stick ini mampu memotong sebanyak $20,29 \mathrm{~kg} / \mathrm{jam}$ dengan efisiensi produksi mesin sebesar 70,02\%.
\end{abstract}

Kata kunci: Kentang, Mesin pemotong kentang, Motor listrik

\section{Abstract}

This research is a design of a potato cutting machine. The ultimate goal of making the machine is the production of potato cubes. In planning the machine will be processed to produce stick-shaped potato pieces. The machine design is made with dimensions of $660 \mathrm{~mm} \times 800 \mathrm{~mm} \times 710 \mathrm{~mm}$ using an electric motor $1 / 2 \mathrm{Hp}$. The system of lowering the rotation uses a pully and belt 1:2 and continued with a gearbox with a ratio of 1:40, the way the engine works is to rotate the crankshaft to move the piston / potato suppressor with a rotation of $17.5 \mathrm{Rpm}$. The study was conducted 3 times with 1000 grams of potatoes with an average yield of 702 grams of good cut, 27 grams unsuccessful, 271 grams behind. The production capacity of this stick-shaped potato cutting machine is capable of cutting as much as $20.29 \mathrm{~kg} /$ hour with a machine production efficiency of $70.02 \%$.

Keywords: potato, potato cutting machine, electric motor

\section{PENDAHULUAN}

Kentang (solanum tuberosum linn) merupakan salah satu tanaman umbi umbian yang memiliki karbohidrat yang tinggi. Wibowo (2015) mengatakan tingginya kandungan karbohidrat menyebabkan kentang dikenal sebagai bahan pangan pengganti beras, jagung, dan gandum. Hal ini kentang banyak digemari oleh masyarakat indonesia. Kentang biasa dibuat berbagai jenis makanan misalnya seperti kentang goreng, keripik kentang, dan sop, dan masakan lainnya. Dalam proses pembuatan masakan sop, maka kentang perlu diolah terlebih dahulu misalnya dikupas, dan dipotong menjadi potonggan stick dan kemudian dipotongan berbentuk dadu. Saat ini kentang cukup sering digunakan untuk pembuatan masakan sop.

Dalam penggunaan kentang untuk pembuatan sop, maka kentang perlu dipotong berbentuk dadu. Sebelum pemotongan kentang berbentuk dadu kentang perlu dipotong berbentuk stick terlebih dahulu untuk memudahkan pemotongan kentang berbentuk dadu. Pemilik usaha kuliner memotong kentang untuk pembuatan masakan sop pada umumnya masih menggunakan cara manual untuk memotong kentang berbentuk stick dalam membuat kentang berbentuk dadu dengan jumlah yang banyak, yaitu memotong dengan menggunakan pisau. Kekurangan saat memotong kentang berbentuk stick menggunakan pisau yaitu memerlukan waktu yang cukup lama dan menguras tenaga dibandingkan memotong kentang menggunakan mesin. Memotong secara manual memiliki resiko kecelakaan kerja yang cukup besar sebab pada saat memotong kentang menggunakan pisau jika tidak hati-hati bisa mengiris tangan pekerja itu sendiri.

Maka dari itu, dilakukan penelitian tentang mesin pemotong kentang. Tujuan akhir dari pembuatan mesin adalah produksi kentang berbentuk dadu. Dalam perencanaan mesin dibuat dua tahap pengerjaan, yaitu proses pertama pemotongan

25 Irwan, Edi, dkk.; Rancang Bangun Mesin Pemotong Kentang Berbentuk Stick 
berbentuk stick, dan kedua proses pemotongan berbentuk dadu. Untuk penelitian ini difokuskan pada proses pertama yaitu pemotongan kentang berbentuk stick.

Mesin pemotong kentang berbentuk stick ini sebelumnya sudah ada tetapi alat sebelumnya masih semi otomatis belum menggunakan motor untuk sistem pengerak poros penekannya tetapi masih mengandalkan tenaga manusia. Mesin pemotong kentang berbentuk stick sangat membantu pemilik usaha kuliner untuk memotong kentang agar efektif dan efisien.

\section{METODE PENELITIAN}

\subsection{Elemen Mesin}

Komponen-komponen mesin pemotong kentang berbentuk stick tersebut terduru dari 7 elemen.

\section{Motor listrik}

Motor listrik adalah suatu mesin yang berfungsi sebagai pengerak untuk memutar poros engkol supaya menekan kentang menuju mata pisau.

\section{Kerangka}

Kerangka berfungsi sebagai penghubung komponen-komponen mesin pemotong kentang berbentuk stick seperti motor listrik, mata pisau, dan lain lainnya. Kerangka terbuat dari baja siku yang telah dibentuk dan kemudian dilas sesuai dengan desain mesin.

\section{Hopper}

Hopper adalah tempat atau wadah penampung kentang sebelum kentang masuk keproses pencetakan stik kentang. Hopper ini terbuat dari stainless steel.

4. Mata pisau

Mata pisau berfungsi untuk memotong kentang supaya berbentuk persegi panjang seperti stick. Mata pisau ini disusun berbentuk kotak-kotak dengan jarak dan ukuran yang sesuai dengan bentuk stick kentang.

\section{Bearing}

Bearing merupakan elemen mesin yang penting berfungsi sebagai tumpuan poros sehingga poros tidak menerima beban gesek dan untuk memperlancar putaran poros dan menghilangkan beban gesek yang terjadi pada poros.

6. Pulley dan belt
Pulley dan belt digunakan untuk mentranmisi daya dari putaran motor penggerak ke elemen yang digerakan, maka diperlukan suatu elemen yang dapat mentranmisikan daya maupun putaran tersebut.

\section{Elemen pengikat (pengelasan, mur, dan baut)}

Elemen pengikat digunakan sebagai pengikat 2 komponen atau lebih, baut dan mur bisa berfungsi sebagai pemegang, penutup, penyetel, dan penyambung yang tidak bersifat permanen.

\section{Metode French}

Sebelum melakukan sebuah proses perancang sebuah alat atau mesin ada beberapa metode penting yang harus dimiliki saat perancangan. Dalam perancangan penelitian yang dibuat ini memilih menggunakan metode french. Alasannya menggunakan metode french karena terdapat desain yang dianggap lebih mudah dipahami, dan mudah dikerjakan dari metode-metode lainnya. Adapun tahapan dari metode perancangan menggunakan metode french adalah sebagai berikut:

1. Analisis masalah ( Problem Analysis )

2. Konseptual desain ( Conceptual Design)

3. 3.Perwujudan skema (Emobodiment Sechema)

4. Perincian ( Detailing )

\section{Diagram alir}

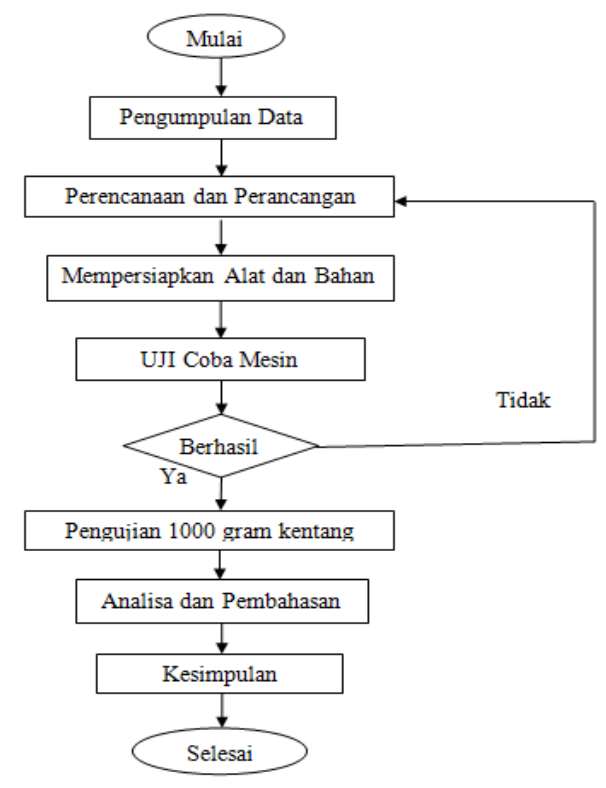

Gambar 1 Diagram Alir

\section{Pengumpulan Data}

Pengumpulan data yaitu mencari data-data yang saling berkaitan dengan judul penelitian dan 
mencangkup segala kebutuhan yang diperlukan. Metode pengumpulan data yang diterapkan antara lain:

\section{Survey Lapangan}

Survei lapangan dilakukan dengan mengunjungi pemilik usaha kuliner yang biasanya membuat masakan menggunakan kentang. Survei ini dilakukan untuk mendapatkan informasi tentang pemotongan kentang untuk digunakan untuk membuat suatu masakan.

\section{Studi literatur}

Studi literatur dilakukan dengan mengunjungi perpustakaan Universitas Bangka Belitung untuk mendapatkan buku-buku referensi yang berhubungan dengan penelitian yang akan dilakukan serta mengunjungi situs internet untuk mendapatkan jurnal-jurnal yang mendukung penelitian.

\section{Wawancara}

Wawancara dilakukan untuk mendapatkan data yang diperlukan dengan mengunjungi pemilik usaha kuliner yaitu bapak Huzaini yang beralamat dikelurahan Bukit Sari Pangkal Pinang untuk mengetahui waktu yang dibutuhkan dalam proses pemotogan kentang secara manual, dan mengetahui ukuran kentang yang dipotong berbentuk stick dan dadu untuk membuat masakan sop.

\section{Bahan}

\section{Motor Listrik}

Motor Listrik yang digunakan adalah motor listrik dengan daya 1/2 HP, dengan kecepatan 1400 rpm.

\section{Belt dan Pulley}

Belt dan Pulley digunakan untuk mentranmisi daya dari putaran motor penggerak ke elemen yang digerakan, maka diperlukan suatu elemen yang dapat mentranmisikan daya maupun putaran tersebut.

\section{Baut dan mur}

Elemen pengikat digunakan sebagai pengikat 2 komponen atau lebih, baut dan mur bisa berfungsi sebagai pemegang, penutup, penyetel dan penyambung yang tidak bersifat permanen.

\section{Bearing}

Bearing merupakan tempat dudukan poros yang berotasi sehingga poros tidak mengalami gesekan langsung.

\section{Profil L baja}

Profil L digunakan untuk membuat rangka mesin sebagai dudukan semua komponen-komponen alat $/$ mesin.

6. Poros

Poros merupakan komponen atau elemen mesin berbentuk silinder yang berfunsi sebagai penerus gaya putar.

7. kayu

kayu digunakan untuk membuat piston atau penekan kentang untuk mendorong kentang kearah mata pisau.

\section{Plat stainless steel \\ Plat stainless steel digunakan untuk membuat hopper dan mata pisau pada mesin pemotong kentang.}

\section{Prosedur Uji Coba Mesin}

Adapun prosedur uji coba mesin pemotong kentang berbentuk stick dapat dilihat sebagai beriut:

1. Siapkan kentang yang telah dikupas.

2. Siapkan mesin pemotong kentang berbentuk stick.

3. Hubungkan mesin ke stop contact.

4. Masukan kentang kedalam hopper pada mesin.

5. Tekan tombol on stop contact pada mesin.

6. Setelah itu catat waktu menggunakan stopwatch dan matikan mesin dengan menekan tombol off pada mesin.

7. Hasil akhir dari uji coba mesin adalah kentang berbentuk stick.

8. Timbang berapa hasil kentang yang terpotong berbentu stick.

\section{Kategori hasil pengujian} sebagai berikut:

Kategori hasil pengujian dikelompokan

a. Berhasil yaitu apabila kentang mampu terpotong berbentuk stick dan bentuk bagaian pinggir kentang disesuaikan dengan kondisi profil kentang.

b. Tidak berhasil yaitu apabila kentang pecah atau patah dan tidak berbentuk stick.

c. Tertinggal yaitu apabila kentang tidak jatuh ke wadah dan tertinggal dimata pisau atau dimesin. 


\section{HASIL DAN PEMBAHASAN}

\section{Gambar Mesin}

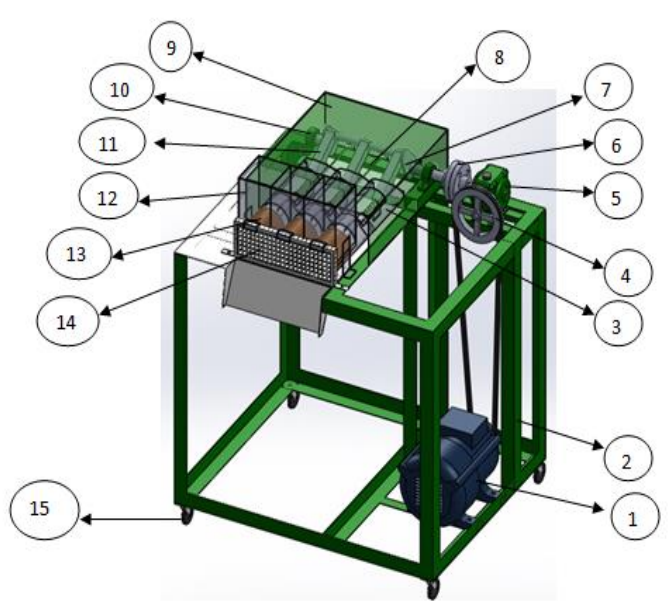

Gambar 2 Mesin Pemotong Kentang

Tabel 1 Komponen mesin dan fungsi komponen

\begin{tabular}{lll}
\hline No & $\begin{array}{l}\text { Nama } \\
\text { Komponen }\end{array}$ & Fungsi Komponen Mesin \\
\hline $\mathbf{1}$ & Motor listrik & Sebagai tenaga penggerak \\
\hline $\mathbf{2}$ & Rangka & Penopang komponen \\
\hline $\mathbf{3}$ & Tabung & Sebagai ruang piston \\
\hline $\mathbf{4}$ & $\begin{array}{l}\text { Pulley dan } \\
\text { belt }\end{array}$ & Mentransmisi daya \\
\hline $\mathbf{5}$ & Gearbox & Sebagai penghantar daya \\
\hline $\mathbf{6}$ & Kopling & Menghubungkan dua poros \\
\hline $\mathbf{7}$ & Poros engkol & Sebagai pengerak piston \\
\hline $\mathbf{8}$ & Penarik & Sebagai penarik piston \\
\hline $\mathbf{9}$ & cover & $\begin{array}{l}\text { Pelindung } \\
\text { mesin }\end{array}$ \\
\hline $\mathbf{1 0}$ & Bearing & Sebagai dudukan poros \\
\hline $\mathbf{1 1}$ & Pendorong & Sebagai penekan piston \\
\hline $\mathbf{1 2}$ & Hopper input & wadah masuk kentang \\
\hline $\mathbf{1 3}$ & Penekan & Sebagai penekan kentang \\
\hline $\mathbf{1 4}$ & Mata pisau & Sebagai pemotong kentang \\
\hline $\mathbf{1 5}$ & Roda & Memudah untuk memindah \\
\hline & &
\end{tabular}

\section{Prinsip Kerja Mesin}

Prinsip kerja mesin pemotong kentang berbentuk stick yaitu dengan cara memanfaatkan putaran dari motor listrik $1 / 2 \mathrm{Hp}$ dengan sistem penurunan putaran menggunakan pulley dan belt 1:2 yaitu pulley satu berdiameter 3 inci dan pulley dua berdiameter 6 inci dan putaran diturunkan lagi oleh gerbox dengan rasio 1:40 sehingga putaran diporos engkol menjadi 17,5 rpm dan poros engkol menggerakan tuas pendorong untuk menekan piston supaya piston bergerak menuju arah mata pisau sehingga kentang terpotong berbentuk stick.

\section{Data Hasil Penelitian}

Hasil yang diperoleh dengan melakukan rangkaian pengujian mesin. Dari hasil yang diperoleh maka akan diketahui berapa kapasitas produksi mesin. Untuk mendapatkan data pengujian tersebut maka dilakukan pengujian mesin dimana pengujian dilakukan sebanyak 3 kali pengujian dengan masingmasing sampel adalah 1000 gram kentang. Bahan uji terdapat pada Gambar 3.

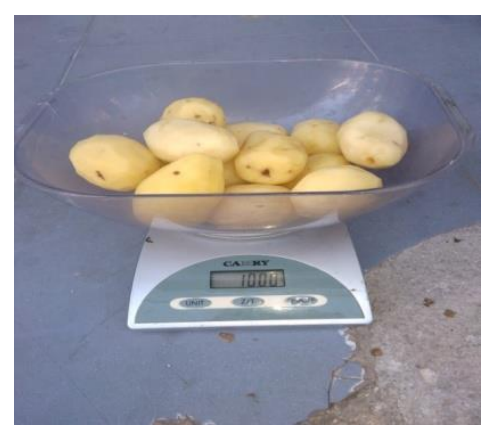

\section{Gambar 3 Bahan uji}

Hasil yang diperoleh selanjutnya diidentifikasi dan dilakukan perhitungan terhadap hasil yang tergolong berhasil dan tidak berhasil dipotong.

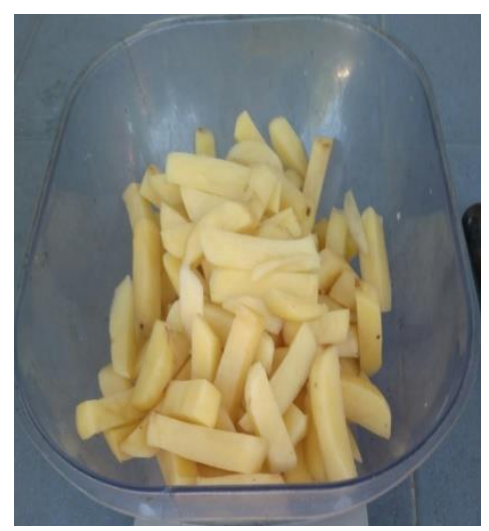

\section{Gambar 4 Hasil Pengujian}

Hasil pemotongan kentang berbentuk stick menggunakan mesin yang telah dibuat dan pengujian dilakukan sebanyak 3 kali menggunakan kentang 1000 gram setiap 1 kali pengujian dapat dilihat pada Tabel 2.

Dari tabel 2 dapat diketahui bahwa hasil pemotongan kentang yang berhasil, tidak berhasil, dan tertinggal adalah 702 gram berhasil, 27 gram tidak berhasil, dan 271 gram tertinggal. 
Tabel 2 Hasil Pengujian

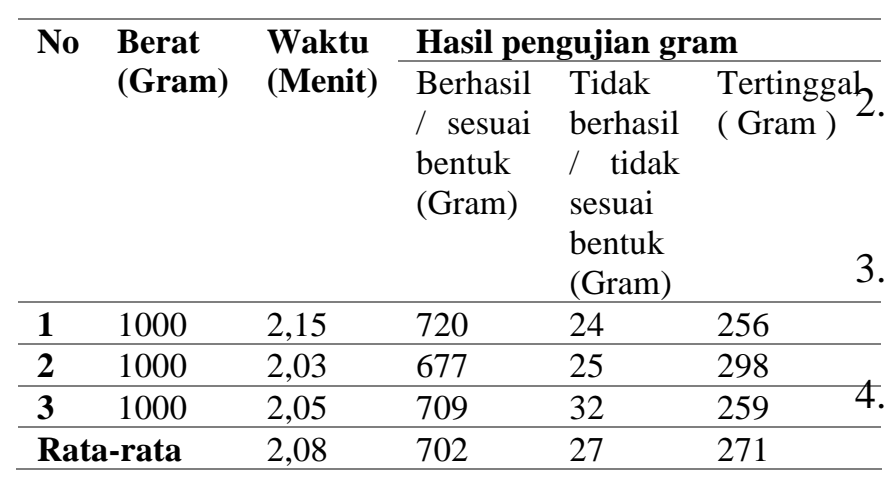

\section{Kapasitas Mesin Pemotong Kentang Berbentuk Stick}

Untuk menghitung kapasitas dari mesin pemotong kentang berbentuk stick yang telah dirancang dihitung rata-rata kentang yang berhasil terpotong pada pengujian yang telah dilakukan dapat dilihat sebagai berikut:

$$
\begin{aligned}
\text { rata-rata } & =\frac{\frac{m 1}{t 1}+\frac{m 2}{t 2}+\frac{m 3}{t 3}}{\text { jumlah sampel }}\left(\frac{\text { gram }}{\text { menit }}\right) \\
& =\frac{\frac{720}{129}+\frac{677}{60}+\frac{709}{60}+\frac{123}{60}}{3}\left(\frac{\text { gram }}{\text { menit }}\right) \\
& =\frac{\frac{720}{2,15}+\frac{677}{2,03}+\frac{709}{2,05}}{3}\left(\frac{\text { gram }}{\text { menit }}\right) \\
& =338,07\left(\frac{\text { gram }}{\text { menit }}\right)
\end{aligned}
$$

Dari hasil perhitungan diatas, output mesin diperoleh adalah 338,07 gram/menit atau dalam satu jam:

$$
\frac{338,07 \mathrm{gram}}{1 \text { menit }}=\frac{0,33807 \mathrm{~kg}}{0,01666 \mathrm{jam}}=20,29 \mathrm{~kg} / \mathrm{jam} \text {. }
$$

\section{KESIMPULAN} bahwa:

Dari hasil penelitian ini dapat disimpulkan

1. Desain mesin pemotong kentang berbentuk stick dibuat dengan dimensi ukuran $660 \mathrm{~mm} \times 800 \mathrm{~mm}$ x $710 \mathrm{~mm}$ ( P x L x T). Menggunakan motor listrk dengan daya $1 / 2 \mathrm{Hp}$. Sistem penurunan puturan menggunakan pully dan belt 1:2 dan diteruskan gerbox dengan rasio 1:140 dengan cara kerja memutar poros engkol untuk menggerakkan pendorong piston dengan putaran $17,5 \mathrm{rpm}$.

. Dari 3 kali pengujian hasil rata-rata pemotongan kentang yang berhasil, tidak berhasil, dan tertingal adalah 702 gram berhasil, 27 gram tidak berhasil, dan 271 gram tertinggal.

3. Mesin pemotong kentang berbentuk stick yang telah dirancang memiliki kapasitas produksi $20,29 \mathrm{~kg} / \mathrm{jam}$.

4. Efesiensi produksi mesin pemotong kentang berbentuk stick yang telah dirancang memiliki efisiensi produksi mesin $70,2 \%$ hasil pemotongan berhasil dan $27,1 \%$ kentang tertinggal.

\section{DAFTAR PUSTAKA}

[1] Indra, Kus. 2019. Modifikasi Mesin Pengiris Bawang Menggunakan Motor Listrik Dengan Daya 200 Watt. Skripsi. Universitas Bangka Belitung.

[2] James R. Thrower,1976. Technical Statics and Strength Of Materials. Buku Halaman 151.

[3] Maizar, Nurul. 2019. Rancang Bangun Mesin Parut Kelapa untuk Pakan Ternak Ayam Sistem Mata Pisau Horizontal. Skripsi. Universitas Bangka Belitung.

[4] Rosa, Firlya, Saparin. 2018. Anlisa Kecepatan Dan Percepatan Poros Ekaentrik Mesin Penubuk Beras Aruk. Skripsi. Universitas Bangka Belitung.

[5] Siti, Amimah. 2015. Pengembangan Alat Pemotong Tipe Manual Menjadi Stick Kentang (Solanum tuberosum). Diploma thesis, Teknologi Pertanian, Universitas Andalas, Padang.

[6] Tri Prasetyo Aji,2017. Rancang Bangun Dan Analisa Struktur Alat Pencetak Nasi Guna Proses Pencetakan Nasi Pada Usaha Katering. Departemen Teknik Mesin Industri. Fakultas Vokasi. Institut Teknologi Sepuluh November Surabaya.

[7] Wibowo, Angga, C. 2015. Perancangan Alat Pemotong Kentang. Teknik Mesin Universitas Negeri Yogyakarta. 